IRISH HISTORICAL STUDIES

\title{
Irish clergy in late medieval England
}

$\mathrm{T}$ This article examines a hitherto unexplored source for the history of the Irish clergy in England - English episcopal ordination lists - to see what they can reveal about Irish clergy in medieval England: their geographic origins, their numbers and, less tangibly, their motivation both for coming to England and for remaining there.

Episcopal ordination lists survive, with gaps, for most English dioceses from the later thirteenth century onwards and are the formal records of the diocesan ordination ceremonies held quarterly by bishops or their suffragans, at which men wishing to be ordained to the priesthood were ordained successively to the orders of acolyte, subdeacon, deacon and priest. The ordination lists can add substantially to our knowledge of the vast mass of the medieval clergy, especially the unbeneficed, who frequently remain almost hidden from the historian. Episcopal ordination lists detail information such as the date and place of ordination, the ordinand's diocese of origin, and occasionally a more precise place of origin and educational qualifications. If the candidate for ordination belonged to a religious order, usually this order and the actual house to which he was attached are listed. Thus these lists can provide a substantial corpus of information, particularly since every member of the clergy ought to be included in the ordination lists as they climbed the ranks of the clerical hierarchy; the same information should be available for everybody, whether they later became an archbishop or found themselves scratching out a living as an underpaid vicar or an unbeneficed mass priest. Over the last few years the computerisation of this material has produced a database of English medieval clergy drawn from the contents of surviving English episcopal ordination lists. ${ }^{1}$

Ordination lists are not unknown in Irish episcopal sources, although there is nothing comparable to the scale of surviving English episcopal registers in the Irish ecclesiastical archives. The Armagh registers contain details of a few ordination ceremonies, although not enough to allow the

'The computerisation project is described in more detail in Virginia Davis, 'The medieval English clergy database - a London case study' in Local Population Studies, i (1993), pp 51-60. Work has been completed on the lists for London and Winchester and the majority of the surviving lists for the whole of England for the period c. $1390-1420$, totalling some 70,000 names. 
compilation of comprehensive lists of the clergy ordained. ${ }^{2}$ Incidental references to ordination recorded there make it clear that successive archbishops of Armagh regarded it as important that men followed the correct procedures of ordination and could prove that they had done so. Archbishop Nicholas Fleming, carrying out visitations in the early fifteenth century, clearly expected priests to be able to produce their letters of ordination when requested, and he followed up those who failed to do so. ${ }^{3}$ In June 1412, for example, Simon Somyrsede of the diocese of Meath was required to produce evidence that he had been fully ordained, and Fleming's register records his production of letters to show that the previous year he had been ordained subdeacon in Tallaght, then deacon in Finglas, and finally priest in Kells, County Meath. ${ }^{4}$

From the point of view of the historian interested in Irish clergy in England, the English episcopal ordination lists, recording information about the diocese of origin of the ordinand, offer an opportunity to identify a particular group of Irishmen abroad, those who found themselves in England at an early stage in their clerical careers and who were ordained there. The lists record for these Irishmen the same sort of material as is recorded for English ordinands, including their diocese of origin, means of support, and place and date of ordination. If they were ordained to more than one order while in England, which is frequently the case, their geographic progress within England can be followed. It is also, as already mentioned in the context of the lists generally, a source which records the humble as well as the élite, the educated who were in England to attend university at Oxford or Cambridge as well as the unbeneficed migrant being ordained perhaps optimistically as the first step in a clerical career which might offer some economic security.

This article explores what can be discovered about this group of Irish secular clerics viewed as a body. Concentration has been on members of the secular clergy, although certainly Irish monks and members of the mendicant orders are also to be found in England. Members of religious orders, however, present particular problems of identification of places of origin, because these men were presented to the bishop for ordination by the religious house to which they were currently attached. Thus no record is given of their place of origin, and the historian is thrown back upon what can be revealed by nomenclature. Names, however, both forenames and surnames, can be surprisingly revealing. There is little doubt, for example, as to the nationality of men such as the Dominican friars Malachy Lyte and Patrick Rede, ordained in Ilchester in Somerset in April 1432, or the friars Dionisus Sligio, ordained in 1443, and Dionisus Powere, ordained in London in $1430 .^{5}$

${ }^{2}$ See, for example, the ordinations held in the diocese of Armagh in 1412-13 in H. J. Lawlor (ed.), 'A calendar of the register of Archbishop Fleming' in R.I.A. Proc., xxx (1912-13), sect. C, nos 218, 223-4 (pp 155-7).

${ }^{3}$ Ibid., no. 141 (pp 136-7).

${ }^{4}$ Ibid., no. 214 (pp 153-4).

${ }^{5}$ The register of John Stafford, bishop of Bath and Wells, 1425-1443, ed. T. S. Holmes (2 vols, London, 1915-16), ii, 330; Reg. Gray, f. 13r-v (Guildhall Library, London, MS 9531/5); Reg. Gilbert, f. 170v (ibid., MS 9531/6). 
The extensive London ordination lists, surviving from 1362, form the core of the information utilised. London clearly emerges as a focus for many of the migrants; thus the trends relating to the men found there appear to be representative, although the loss of the ordination lists for the lengthy episcopate of Thomas Kempe (1450-89) means that there is a considerable gap in the sources. The London material has been supplemented by all the printed registers for late medieval England which have been searched, plus the unpublished material for the dioceses of Canterbury, Lincoln and Ely to 1500 . It would be in these latter two dioceses that one might expect to find a number of Irishmen who were in attendance at Oxford and Cambridge respectively, although many who were in England in pursuit of education also appear among the ordainees in London. ${ }^{6}$

How big was the body of Irish secular clerks ordained in England in the late middle ages? To date, 216 secular clerics ordained in England have been identified for the period 1350-1500..$^{7}$ This is therefore a smallish group, but not insignificant: one newly identified and of relevance in exploring the issues arising from the presence of the Irish in medieval England. The geographic origins of these men, the places they went to in England and the timing of their exodus are all of interest.

Within the diocese of London itself, the Irish ordinands represent about 1.75 per cent of the total number of secular clergy ordained; 363 entries in the lists refer to Irishmen in a total of just over 20,000 entries of secular clergy. ${ }^{8}$ Although that does not seem a very large number, the Irish were more numerous than other groups of clergy from some other parts of the British Isles or from continental Europe. ${ }^{9}$ To give an idea of scale, almost as many men from the diocese of Meath alone were ordained in London as from the Welsh diocese of Bangor; across the period as a whole, 37 men

${ }^{6}$ Of the London registers, only that of Simon Sudbury has been edited: Registrum Simonis de Sudburia diocesis Londoniensis, 1362-1375, ed. R. C. Fowler and Claude Jenkins ( 2 vols, Oxford, 1927-38). The manuscript registers for the diocese of London are in the Guildhall Library, London. Details of episcopal registers for England and Wales can be found in D. M. Smith, Guide to bishops' registers (London, 1981), pp 136-49.

${ }^{7}$ The records of the ordinations of these men will be published by the present writer in full in Archiv. Hib., liv (2000).

${ }^{8}$ The number of entries in the database is not the same as the number of people, since each entry represents one entry in the original ordination lists. Individuals may well occur more than once in the lists as they are ordained at the successive stages of ordination.

${ }^{9}$ Details of some of the continental clergy coming to England can be found in Virginia Davis, 'Transcending the regions: mendicant mobility in the English church in the later middle ages' in Francesca Bocchi and Peter Denley (eds), Storia et multimedia: proceedings of the Seventh International Congress, Association for History and Computing (Bologna, 1994), pp 369-74. 
came from Meath, while 42 came from Bangor. The Irish were far more numerous than the Scots or the French. Who were they? They are likely to have been regarded as being Irish by those who were ordained with them; yet although not exclusively Anglo-Irish, the majority came from the Anglo-Irish community, as evidenced by their names: men from families such as Poer, Picard, Stacbole, Whiteside, Cusac and Leddred. When the lists of Irish clergy ordained in England are compared with the surviving Armagh ordination lists in the late middle ages, it can be seen that the latter often show a much more mixed ethnic grouping, with substantial numbers of men with Gaelic names being ordained. This can be seen, for example, from the names of those men ordained as deacons in the diocese of Armagh in March 1413, at least three of whom appear to be Gaelic in origin. Five men were ordained deacon: Henry Rede, Nicholas Heyn, Charles Omoloyn, Avelanus Omolcahelyn and John Omoloyn. ${ }^{10}$

Predominantly the men who went to England to be ordained throughout the later middle ages came from the heartland of the colony, the dioceses of Meath, Dublin, Armagh and, to a lesser extent, Kildare, Ossory and Ferns, but there were also a handful of representatives from a substantial number of other dioceses. Nineteen Irish dioceses are represented by men ordained in England in the century 1350-1450, but over half the men ( 94 of 167) came from the three dioceses of Meath (33), Armagh (32) and Dublin (29), while a further 36 came from Kildare (15), Ferns (11) and Ossory (10). ${ }^{11}$ In a few individual cases the ordinand's precise place of origin within the named diocese is given. When this is the case, the information largely reinforces the above impression of a colonial clergy: Matthew Molen came from Lucan, County Dublin; Robert Cormok from Kilkenny; John Hardyng from Hardingston in the diocese of Armagh; Thomas Waleys from Momdessel in County Tipperary. ${ }^{12}$

A substantial proportion of these Irish clerks were ordained in the diocese of London; the remainder were scattered over a number of other dioceses. ${ }^{13}$ This is not just an impression created by a bias in the sources; as opposed to sixteen men in London for the period 1390-1420, the diocese of Ely produces only six individuals, while only a single Irish clerk is named in the diocese of Canterbury in the same period. Langland's claim in Piers

${ }^{10}$ Lawlor (ed.), 'Calendar of Archbishop Fleming's register', no. 223 (p. 157).

${ }^{11}$ Men also came from the dioceses of Achonry (1), Ardfert (1), Ardmore (2), Cashel (5), Clonfert (1), Cloyne (3), Connor (3), Cork (3), Down (1), Emly (2), Kilmore (1), Leighlin (2), Limerick (6), Tuam (1), Waterford and Lismore(4).

${ }^{12}$ Molen was ordained in June 1398 in London (Reg. Braybrooke, f. 48v (Guildhall Library, London, MS 9531/3)). Cormok was ordained in St Paul's cathedral in London in 1364 (Reg. Sudbury (London), ii, 26, 28). John Hardyng of Hardingston was ordained in Oxford and Winchester in 1461 (Reg. Waynflete, f. Yr-v (Hampshire Record Office)). Thomas Waleys was ordained in London in 1361-2 (Reg. Sudbury (London), ii, 2, 4,5).

${ }^{13}$ Irish are found in the ordination lists of the following dioceses: Bath and Wells, Coventry and Lichfield, Canterbury, Ely, Exeter, Hereford, Lincoln, London, Rochester, Salisbury, Winchester and Worcester. They have not been found in Chichester, Carlisle, Durham, Gloucester, Norwich and York. 
Plowman that clergy were drawn to the potential of London is borne out by the evidence in the case of the Irish clergy. ${ }^{14}$ One might expect to find more Irish in the south-west, perhaps entering England through Bristol and the Devon coastal ports, ${ }^{15}$ but this does not seem to have been the case, with only two men to be found in the diocese of Exeter (Devon and Cornwall) for the fifty-year period 1370-1419 for which the records are complete. ${ }^{16}$ Additionally six men are found in the diocese of Worcester in the period 1375-95. ${ }^{17}$ Little can be said about the county of Somerset, since there are no ordination records for the diocese of Bath and Wells before 1408 , but even after that date few Irishmen are found ordained there. The situation in the diocese of Salisbury, which covered the area of Wiltshire,

${ }^{14}$ William Langland in his Piers Plowman, written in the 1370 s, deplored the lure of London for those in clerical orders, leading to the neglect of their own pastoral responsibilities: "Then I heard parish priests complaining to the bishop that since the plague their parishes were too poor to live in; so they asked permission to live in London where tiley could traffic in masses and chime their voices to the sweet jingling of silver' (Langland, Piers the Ploughman, ed. and trans. J. F. Goodridge (revised ed., Harmondsworth, 1966), p. 27).

${ }^{15}$ The image of large numbers of Irish entering through the south-west may be exaggerated; it is clear that Irish merchants' activity outside Chester, Bristol and Bridgwater was limited. Customs accounts show that Devon and Cornwall had one or two Irish ships in a year (Wendy Childs and Timothy O'Neill, 'Overseas trade' in Art Cosgrove (ed.), A new history of Ireland, ii: Medieval Ireland (Oxford, 1987), p. 512).

${ }^{16} \mathrm{John}$ Stevyn of Dublin was ordained acolyte in Clyst manor chapel in 1392 (The register of Thomas de Brantyngham, bishop of Exeter, ed. F. C. Hingeston-Randolph (2 vols, London \& Exeter, 1901-6), ii, 875), while William Walsh of Cloyne diocese was ordained priest at Crediton college in Exeter in 1409, having been previously ordained subdeacon and deacon in the diocese of Salisbury (The register of Edmund Stafford, ed. F. C. Hingeston-Randolph (London \& Exeter, 1886), p. 466; The register of Robert Hallum, bishop of Salisbury, 1407-1417, ed. J. M. Horn (Torquay, 1982), nos 1030-31 (pp 161-3)).

${ }^{17}$ Thomas Bele of Dublin diocese was ordained acolyte in May 1390 at Hartlebury episcopal chapel in Worcestershire ( $A$ calendar of the register of Henry Wakefield, ed. W. P. Marett (Leeds, 1972), p. 209). Richard Boys of Meath diocese was ordained subdeacon in Kidderminster church in March 1379 (ibid., p. 175). Robert Fossard of Ossory diocese was ordained successively deacon and priest in March 1403 in Llanthony priory and Hartlebury castle in March 1403 (The register of Richard Clifford, bishop of Worcester, 1401-1407, ed. W. E. L. Smith (Toronto, 1976), pp 78, 80 ), with a title from Rewley abbey in Oxfordshire which may suggest a link with the University of Oxford. Peter Smyth of Dublin diocese was ordained acolyte in Lambeth Palace in London on 20 September 1376 and subsequently as deacon and priest within the diocese of Worcester at an unknown date and place between c. 1378 and c. 1381 (Reg. Sudbury (Canterbury), f. 139v (Lambeth Palace Library); Reg. Wakefield, pp 179, 181). Nicholas Whyte from Armagh diocese was ordained priest in early March 1393 in Alvechurch parish church with a title from John Dovedale (Reg. Wakefield, p. 220). Nicholas Wynsy of Ossory diocese was ordained acolyte and subdeacon in a single day in March 1394 in Worcester cathedral (ibid., p. 221). Both Peter Smyth and Nicholas Wynsy (as Wonsy) appear listed as chaplains among the 1394 exemptions (Cal. pat. rolls, 1391-6, pp 468, 463). 
Berkshire and Dorset, is similar: surviving records for the thirty-year period $1396-1426$ produce only six names. ${ }^{18}$ Surprisingly, fewer Irish clerics are also found being ordained in the diocese of Ely (which included the University of Cambridge) than might be expected. For the diocese of Ely for the substantial period 1370-1422 for which records are complete there are just nine names. ${ }^{19}$ It is more difficult to ascertain the numbers of Irish ordained in the huge diocese of Lincoln in this period, because no ordination lists survive for the diocese between 1363 and 1398, and again between

${ }^{18}$ William Collan of Armagh diocese was ordained deacon in St Paul's cathedral in
London in March 1421, and in September of the same year as priest in Salisbury
cathedral (The register of Henry Chichele, archbishop of Canterbury, ed. E. F. Jacob (4 vols, Oxford, 1938-47), iv, 344; Reg. Chaundler, f. 39v (Wiltshire Record Office)). William Haddesford [Hadsor], also of Armagh was ordained deacon at the same ceremony in Salisbury cathedral in September 1421 (ibid., f. 39r). Haddesford was later to become bishop of Meath. His career is listed in A. B. Emden, Biographical register of the University of Oxford (3 vols, Oxford, 1957-9) (henceforth cited as B.R.U.O.). Philip Martyn alias Randolf of Cloyne diocese was ordained deacon in September 1400 at Potterne church in Wiltshire (Reg. Mitford, f. 170r (Wiltshire Record Office)). William Walsh alias More of Cloyne diocese was ordained subdeacon and deacon in Salisbury diocese in September and December 1408, moving on to Crediton in Devon for his ordination as priest in December 1409 (Reg. Hallum, nos 1030-31 (pp 161-3); Reg. Edmund Stafford, p. 466). John de Weyford [Wexford] of Ferns diocese was ordained priest in Salisbury in 1406 (Reg. Mitford, f. 178v). Thomas White of Armagh diocese was ordained deacon in September 1420 in Sonning in Berkshire before moving to Wells for ordination as priest in December of the same year (Reg. Chaundler, f. 37r; The register of Nicholas Bubwith, bishop of Bath and Wells, ed. T. S. Holmes (2 vols, London, 1914), ii, 345).

${ }^{19}$ Adam Bryt of Kildare diocese was ordained acolyte, subdeacon and priest between March and June 1408 in the diocese of Ely, with a trip to St Paul's cathedral in London for ordination as deacon in April of the same year (Reg. Fordham, ff $246 \mathrm{v}$, 247v (Cambridge University Library, EDR G/1/3); Reg. Clifford, f. 38v (Guildhall Library, London, MS 9531/4)). Robert Crull of Dublin was ordained acolyte and subdeacon in Ely in 1416-17 (Reg. Fordham, ff 266r-267v). John Deveros of Limerick diocese was ordained to all four orders between September 1377 and June 1378 in the diocese of Ely (Reg. Arundel, ff 121v, 123r (Cambridge University Library, EDR G/1/2)); in August 1394 he was licensed as an Irishman by birth to remain in England (Cal. pat. rolls, 1391-6, p. 469); for his subsequent career as an anti-Wyclifite theologian see A. B. Emden, Biographical register of the University of Cambridge (Cambridge, 1963) (henceforth cited as B.R.U.C.) p. 186. Nicholas Hert of Kildare was ordained to the major orders in Ely cathedral between December 1420 and March 1421 (Reg. Fordham, ff 108r-v, 109r). William Kyltale of Meath was ordained acolyte in Ely cathedral in September 1378 (Reg. Arundel, f. 123v). Nicholas Lang of Dublin diocese was ordained subdeacon and deacon in Ely in 1411, moving to London before his ordination as priest in September 1411 (Reg. Fordham, f. 249v; Reg. Clifford, f. 55v). Andrew McConaghty, already beneficed as a priest in Connor diocese, was ordained priest in Dodington manor chapel in March 1394 (Reg. Fordham, f. 235r). Donald Omery of Achonry was ordained deacon in September 1418 in Downham manor chapel (ibid., f. 270v). John Walsh of Ferns diocese was ordained to all orders within the diocese of Ely between September 1407 and June 1408 (ibid., ff $246 v, 247$ r). Of these men, only Deveros is definitely known to have been in attendance at Cambridge. 
1405 and 1420; however, the lists for the period 1398-1405 yield only two Irish names, which does not suggest that substantial numbers were ordained in that diocese, despite the fact that it encompassed seven English counties $^{2()}$ and included the University of Oxford.

With London clearly identified as the major site for Irish clergy in England, the surviving London material can be used to illustrate trends in immigration. Since the London lists only begin in 1361 - after the Black Death - there is again a bias in the sources. Nonetheless, it looks as if the immigration into England of substantial numbers of clergy is certainly a post-Black Death phenomenon. Sampling of evidence for the earlier fourteenth century from other English dioceses suggests very few Irish. For example, Winchester, a diocese for which fourteenth-century records are complete, records only two Irishmen being ordained in the first half of the century, compared with fifteen in the second half.

\section{Numbers of Irishmen ordained in London, 1360-1450}

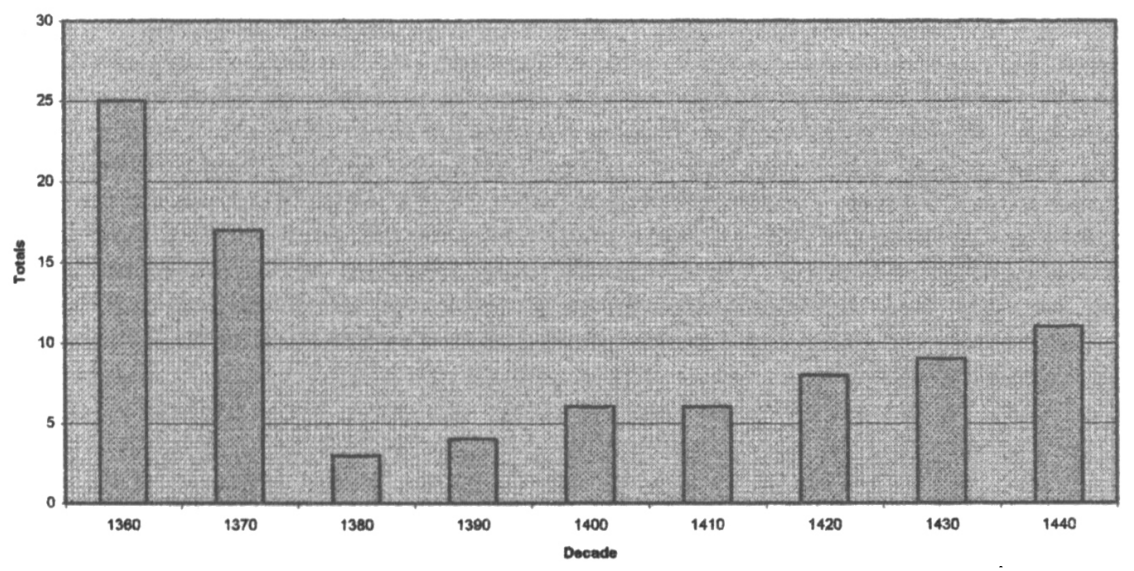

Certain periods can be defined as peak periods of Irish clerical ordination in London. The 1360s and 1370s stand out as the primary peak, with ordinations subsequently dropping away dramatically in the $1380 \mathrm{~s}$ and then picking up again in the $1390 \mathrm{~s}$, though never to more than about two-thirds of the former numbers. The drop in the figures for the $1380 \mathrm{~s}$, however, is not the result of dramatic events in either England or Ireland, but is rather due to the loss of the London register of William Courtenay, bishop of London $1375-82 .{ }^{21}$ In fact the figures for the 1370 s only relate to the first half of the

${ }^{20}$ The medieval diocese of Lincoln covered the counties of Lincolnshire, Leicestershire, Bedfordshire, Oxfordshire, Buckinghamshire, Northamptonshire, Rutland, Huntingdonshire and part of northern Hertfordshire.

${ }^{21}$ One of the entries for 1380 is from the register of Canterbury, but the ordination ceremony actually took place at Lambeth Palace in London, so for the purposes of geographic analysis it has been included in the London figures. 
decade, and the real total is likely to have been closer to that of the $1360 \mathrm{~s}$. The decline in total numbers in the $1390 \mathrm{~s}$, however, is real, rather than a trick of the evidence and is likely to reffect the stress being placed by the government of Richard II on tackling Irish absenteeism. ${ }^{22}$

There are some hints of a further upswing in the numbers in the 1430s and 1440s, but the loss of the records for the diocese of London from 1448 to 1489 means that this cannot be explored further. Other dioceses, such as Lincoln and Canterbury, have such small numbers of Irish ordinands that it is not possible to use these figures to draw satisfactory conclusions as to trends.

Numbers of Irishmen clearly continued to come to England in the fifteenth century. This was a matter of dual concern to the authorities, both because of absenteeism from Ireland and also because there were complaints that Irishmen were a disruptive influence in England. ${ }^{23}$ These concerns were expressed in 1413 when the English parliament was concerned with the perennial problem of non-residence of Irishmen in Ireland, to which was attributed some of the problems facing the colony:

Item, for peace and quiet within realm of England and for the increase and stocking of the land of Ireland, it is ordained in this present parliament that all Irishmen and Irish begging clerks called chamberdeakyns, be sent out of the realm between the feast of St Michael next and the feast of All Saints next, on pain of losing their goods and being imprisoned; except those who are graduates in the schools and serjeants and apprentices of the law and those who have inherited in England and religious persons professed ... and that all those Irishmen who have benefices or offices in the land of Ireland dwell on their offices and benefices, on pain of losing and forfeiting the profits of their benefices and offices, for the defence of the land of Ireland aforesaid. ${ }^{24}$

Why did Irish clergy come to England and get ordained there in the generation after the Black Death? This can be explained by a combination of factors, both Irish and English. First, there was the clerical situation in England itself. In the first half of the fourteenth century, as demonstrated by English ordination lists of the period, there were enormous numbers of men coming to be ordained as priests, far more than could be catered for by established positions within the church. In the latter part of the century, as the demographic downturn affected the church as well as lay society, there were fewer men entering the church, yet the numbers of parishes remained roughly the same. At the same time the growth of positions for

${ }^{22}$ On Richard II's policy towards Ireland see J. F. Lydon, 'Richard II's expeditions to Ireland' in R.S.A.I. Jn., xciii (1963), pp 135-49; Anthony Tuck, 'Anglo-Irish relations, 1382-1393' in R.I.A. Proc., lxix (1970), sect. C, pp 15-31.

${ }^{23}$ Ralph A. Griffiths, The reign of Henry VI: the exercise of royal authority, 1422-61 (London, 1981), pp 134-5, 142-3, 167-8.

${ }^{24}$ Stat. of realm, ii, 173. 
unbeneficed priests in chantries and as mass priests offered new opportunities to men entering the church, even if they lacked the patronage to enable them to become beneficed.

This enhancement of clerical opportunities in England coincided with increasing difficulties being faced in Ireland. The shrinking of the area under the control of the Dublin government reduced opportunities for Anglo-Irish clergy to obtain and hold peaceful benefices in Ireland, thus making the possibilities of emigration more attractive to aspiring clerics as well as to those in other professions. The continued decline of the colony after the expedition of Lionel of Clarence may well have rendered the prospect of ministering to people there increasingly unattractive, leading to a shortfall in the number of priests needed to fill vacant positions in the diocese. ${ }^{25}$ Archbishop Thomas Minot's provincial council of 1366 made it clear that Gaelic lrish clergy were ministering widely within the lordship and sought to ensure that Irishmen who were ordained were politically reliable by requiring them to take an oath of loyalty prior to ordination. ${ }^{26} \mathrm{At}$ the same time the Statute of Kilkenny also legislated concerning the Irish clergy who were benefice-holders within the colony, ministering to the Anglo-Irish community, by requiring them to use the English language. ${ }^{27}$ In addition to dealing with the current position where Gaelic Irishmen held benefices, the Statute of Kilkenny also legislated against their future appointment to benefices: 'Further it is ordained that no Irishman of the nations of the Irish shall be admitted to any benefice of holy church amongst the English of that land.' This was not to be workable in the absence of sufficient Anglo-Irish priests, as is evidenced by the existence of licences for Irishmen to hold benefices among the English. ${ }^{28}$

Some lists of Irishmen in England surviving from administrative records in the late middle ages assist in the exploration of the motives for Irish clerical migration. The most extensive and useful of these lists is that of Irishborn men who had paid for the right to remain in England in 1394. That at least some of the men who came to England and were ordained there came to stay, not merely to obtain a university education unavailable to them in Ireland, is strongly suggested by an examination of some of the individual experiences of the clerics who in 1394 sought exemption from the statute requiring the return to Ireland of those born there but now resident in England. The list of those exempted from the parliamentary order to return in 1394 reveals Irish clerks holding English benefices and provides evidence

\footnotetext{
${ }^{25}$ Anthony Lynch makes the point that only three or four priests were being ordained annually in the diocese of Armagh (Anthony Lynch, 'Religion in late medieval Ireland' in Archiv. Hib., xxxiv (1981), p. 10).

${ }^{26} \mathrm{~J}$. A. Watt, The church and the two nations in medieval Ireland (Cambridge, 1970), pp 205-6.

${ }^{27}$ Ibid.: 'Those holding benefices of holy Church among the English shall use the English language, and if they do not do so, their ordinaries shall have the issues of their benefices until they do use the English language in the manner aforesaid.' The full text is in Aubrey Gwynn, 'Provincial and diocesan decrees of the diocese of Dublin during the Anglo-Norman period' in Archiv. Hib., xi (1944), pp 100-1.

${ }^{28}$ Watt, Church \& two nations, p. 207.
} 
for the study of the occupations of clerical Irishmen. In 1394 there were 101 men referred to as chaplain, 12 as clerk, 1 priest, 1 parish clerk, 13 parsons and 11 vicars; a total of 139 men in all. Of the total of 249 Irishmen listed in the patent rolls, ${ }^{29} 53$ per cent of the total were secular clerics of some sort. ${ }^{30}$

Some of the men described as 'chaplain' or 'clerk' on the exemption lists held parochial benefices in England. It is difficult to trace the careers of many of them, but a number of the men can also be traced in the English ordination lists. Where this is the case, the ordination lists provide details of Irish diocese of origin and give some sense of how long the men in question might have been in England. Adam Breakspere may be identified with the man of that name, originally from the diocese of Meath, ordained acolyte, subdeacon and deacon in London almost thirty years earlier, between 1366 and 1368, with a title from the nuns in Clerkenwell. ${ }^{31}$ Patrick FitzGerot is likely to be the man of the same name, described as from Kildare diocese, ordained acolyte in Farnham in Surrey ten years before in September 1384, and deacon in London in late $1386 .{ }^{32}$ It is also possible to trace some of the careers of those men listed in the exemption lists who were also beneficeholders, and this evidence suggests that these were not men who appear to have come for higher education but rather were economic migrants who had found a niche in England and did not propose to return to Ireland. James FitzHugh, described in the 1394 exemption lists as parson of Oxted in Surrey, had been holding that benefice since 1390; previously he had been rector of the Cambridgeshire parish of East Hatley, and subsequently, in 1398, he exchanged his benefice, this time for a Welsh parish, that of Caerleon in Llandaff diocese. ${ }^{33}$ Patrick Swayne, rector of Farnborough in Berkshire in 1394, had previously been vicar of Fisherton de la Ware in Wiltshire, which was worth 10 marks a year. ${ }^{34}$ Richard Montayne was

${ }^{29}$ Cal. pat. rolls, $1391-6$, pp 451-65, 468-9.

${ }^{30} \mathrm{Clergy}$ form a much smaller proportion of the total listed in the alien subsidy taken in 1440: there are only 24 secular clerks ( 4 vicars, 3 priests, 2 chantry priests, 11 chaplains, 4 rectors) of a total of 243 Irishmen, just under 10 per cent of the total (P.R.O., E 179, lay subsidy rolls, alien subsidy 18-19 Hen. VI). This may reflect a difference in the way in which they were recorded. I am very grateful to Professor J. L. Bolton, who provided me with this material. See J. L. Bolton, 'Irish migration to England in the late middle ages: the evidence of 1394 and 1440' in I.H.S., xxxii, no. 125 (May 2000), p. 16.

${ }^{31}$ Registrum Simonis Langham, Cantuariensis archiepiscopi, ed. A. C. Wood (Oxford, 1956), pp 375, 383; Reg. Sudbury (London), ii, 55.

${ }^{32}$ Wykeham's register, ed. T. F. Kirby (2 vols, London, 1896-9), ii, 308; Reg. Braybrooke. f. 16v (Guildhall Library, London, MS 9531/3).

${ }^{33}$ Reg. Wykeham, i, 176, 216. The patron of Oxted was a secular knight, Reginald Cobham.

${ }^{34}$ There is a description of Fisherton vicarage at this period, from an episcopal inquiry made in 1394 for the purpose of appropriating the parish to its patrons, the priory of Maiden Bradley. It suggests a peaceful setting: 'It [the vicarage] had a house with dovecote and adjoining garden; also a virgate of arable . . 1 acre of common meadow and a separate meadow called "Paradys". There were extensive tithes attached to the position (The register of John Wallham, bishop of Salisbury, 1388-1395, ed. T. C. B. Timmins (Woodbridge, 1994), no. 123 (pp 33-4)). 
described as vicar of Ambresdon in Oxfordshire in 1394; ten years later in 1404 he was holding Llanarmon parish in the Welsh diocese of St Asaph and was provided to the Ferns canonry and prebendary of Taghecomschan. ${ }^{35}$

Other fourteenth-century evidence also suggests that clerics who went to England might well be in no hurry to return to Ireland, even when they were holding benefices in the colony. In 1369 King Edward III wrote to the bishops of Ireland, requiring them to sequestrate the revenues of men holding ecclesiastical benefices in their dioceses who were resident outside Ireland. The bishops were required to certify the amount of such revenues and the names of the beneficed. ${ }^{36}$ Replies to this request have survived from only a few dioceses, but the few which do survive indicate the names of non-residents, details of the parishes they held and their value and a reason for their absence from Ireland. Thus from the diocese of Armagh we have details of four men - Andrew Waryng, David Brakdan, John Cusack and James Stantoun - all of whom are described as being in England in order to study, Stantoun, Waryng and Brakdan at Oxford, Cusack at an unnamed studium generale. ${ }^{37}$ Three of the four can be matched up with names from the English episcopal ordination lists. These reveal that these men had been in England since at least early in the decade. Andrew Waryng, rector of Beaulieu, County Louth, a valuable benefice worth 10 marks a year, had been ordained priest in Chelmsford parish church in September 1362. At that stage he was unbeneficed; his Irish preferment clearly came later — by 1369 at any rate — but had not yet drawn him back to Ireland. He was still non-resident in $1381 .{ }^{38}$ Likewise, David Brakdan, rector of Darver, County Louth, worth 13 marks a year, had been ordained deacon and priest in 1363 in the diocese of London, again when unbeneficed. ${ }^{39}$ John Cusack, a member of a prominent Anglo-Irish family in County Meath, was already beneficed with the rectory of Rath[drumin] when in $1364 / 5$ he was ordained in the diocese of London. ${ }^{40}$

Further evidence which illuminates the background and experiences of Irish clerics ordained in England is provided by an examination of the titles offered at their ordination by men from Ireland. This evidence too helps

${ }^{35}$ Cal. papal letters, $1396-1404$, p. 614 . He may be related to Robert Montayne, bishop of Meath 1401-12, who was proctor of the province of Armagh to the council of Pisa in 1409 (B.R.U.O., p. 2198).

${ }^{36}$ The register of Milo Sweteman, archbishop of Armagh, 1361-1380, ed. Brendan Smith (Dublin, 1996), document 60 (pp 58-9).

${ }^{37}$ Ibid., document 62 (pp 60-62), schedule of beneficed persons from the diocese of Armagh.

${ }^{38}$ Reg. Sudbury (London), ii, 12; Paul Brand, 'The formation of a parish: the case of Beaulieu, Co. Louth' in John Bradley (ed.), Settlement and society in medieval Ireland (Kilkenny, 1988), p. 271.

${ }^{39}$ Reg. Sudbury (London), ii, 19, 21. He had previously been ordained acolyte in Oxford in February 1362 (Reg. Gynwell, f. 111 (Lincolnshire Archives Office, Episcopal Register (XD)).

${ }^{40}$ Reg. Sweteman, document 62 (pp 60--62); Reg. Sudbury (London), ii, 29, 36. 
further in identifying their connexions and means of support, which may in turn also reveal more about their motivation for coming to England. When a secular clerk was ordained, details of his benefice, if any, were recorded, or, alternatively, his means of sustenance if he were not beneficed. This information, known as his title, was recorded mainly to protect the bishop, who was supposed to have satisfied himself that the men whom he was ordaining had adequate means of support. In the thirteenth-century and early fourteenth-century lists such titles are often spelt out in some detail; later changes in administrative practice make the interpretation of the recorded information more difficult. ${ }^{41}$ Acceptable titles included possession of a benefice, with or without cure of souls, possession of a private income, sponsorship from a lay or religious person, attachment to a collegiate institution, and a title from a named religious house. Irishmen ordained in England present examples of all the normal range of titles.

Most, though not all, of the men listed as holding a benefice at the time of their ordination (not a very desirable state of affairs from the perspective of canon law) were holding benefices situated in Ireland. In most cases they had reached the final stages of the ordination process and were being ordained as priests. ${ }^{42}$ As was often the case in England, those who were already beneficed at this early stage of their careers were high-flyers, already with supportive patrons and likely to succeed in the church. Into this category would certainly come Master John Swayne of Kildare diocese, the future archbishop of Armagh, who was ordained in London in the autumn of 1415 and spring of 1416 with a title which shows that he was already holding the rectory of Upminster in Essex. ${ }^{43}$ Similarly well favoured was Thomas de Dene who, when he was ordained priest in Chelmsford in Essex in 1362, was described as archdeacon of Ferns, a post he had held since 1356. His father had been seneschal of Wexford, and Thomas's ordination to the priesthood was rapidly followed by his promotion to the bishopric of Ferns. ${ }^{44}$ The remainder of benefice-holders may well have been in pursuit of education; with a benefice in Ireland, it may have been their intention - unlike the unbeneficed - to return to Ireland, though the experience of Andrew Waryng, cited above, suggests that many did not. Some are known to have at least retained links with Ireland, men such as the theologian John Whitehead, holder of the parish of Stabannan, County Louth, who had studied at Oxford and who subsequently acted as a proctor of the archbishop of Armagh in attending the council of Pisa in

\footnotetext{
${ }^{41}$ See below, p. 157.

${ }^{42}$ One person holding an English benefice at the time of his ordination was John Hardyng, of Hardingston in the diocese of Armagh, who was ordained in 1461, described as priest of Loxford in the diocese of Exeter (Register Waynflete ff $\mathrm{Xv}$, $\mathrm{Yr}-\mathrm{v}$ ) (Hampshire Record Office)). Nothing is known of the patronage which lay behind his promotion to this benefice.

${ }^{43}$ B.R.U.O., p. 2219. Swayne was in fact rector of Galtrim, County Meath, by 1404 ; acolyte, 22 Sept. 1414; subdeacon, 22 Dec. 1414; deacon, 23 Feb. 1415; priest, 16 Mar. 1415 (Reg. Clifford, ff 70r, 71r, 72r, 73r (Guildhall Library, London, MS 9531/4)).

${ }^{44}$ J. B. Leslie, Ferns clergy and parishes (Dublin, 1936), pp 4, 50; B.R.U.O., p. 567.
} 
$1409 .{ }^{45}$ Other beneficed men whose future career remains obscure included Master William Castlemartyn, whose title was from Kilskeer parish in County Meath (1376), Thomas Ottahill, who held Mahoonagh parish in the diocese of Limerick (1365), and Andrew McConaghty, who held Chevton in Connor diocese (1394). ${ }^{46}$ Other beneficed men held posts without the cure of souls, attached to Irish cathedrals, such as Philip Ray, canon of the cathedral of Lismore in 1370, or Thomas Rys, canon of Cork cathedral in 1372. ${ }^{47}$

\section{IV}

Many of the men had titles derived from religious houses. As with English candidates for ordination, these represent the majority of titles for orders. This appears to reflect not a commitment on the part of the house to sustain the ordinand, but rather an administrative procedure whereby the house concerned was really certifying that it had 'checked' the title in some way and found that it was acceptable. ${ }^{48}$ These titles come to predominate in the later middle ages. ${ }^{49}$ Unfortunately they hide the real source of the funds which supported the ordinand and make it more difficult to examine the sorts of sponsorship which assisted men to enter the church. On occasion, however, some hints slip through, and in fact they do so more often with men from outside England, who were not always aware of the more normal administrative procedures and may have turned up at ordination with the evidence of their real title rather than the certification of a religious house.

The range of religious houses listed as providing titles for Irishmen being ordained in England is wide, and is likely to reflect at least a visit to the house by the ordinand in question. For very many English ordainees, when it is known precisely where they came from, it is clear that often such men approached a house close to their home to have their title certified.

\footnotetext{
${ }^{45}$ Whitehead was active as a theologian in England for much of his career, but at the same time he retained Irish links and in 1422 unsuccessfully laid claim to a prebend of St Patrick's cathedral in Dublin; his career is briefly described in B.R.U.O., p. 2037.

${ }^{46}$ Neither Castlemartyn nor Ottahill are listed in J. B. Leslie's typescript succession lists to the dioceses of Meath and Limerick respectively (Representative Church Body Library, Dublin, MS 61/2); Kilskeer, County Meath, was held by John Taaff by 1385. McConaghty is not listed in J. B. Leslie, Clergy of Connor (Belfast, 1993).

${ }^{47}$ Philip Ray is listed as an otherwise unidentified member of the Waterford clergy in 1376, and a man of the same name is described as a late fourteenth-century precentor of Lismore cathedral (W. E. Rennison, Succession list of the bishops, cathedral and parochial clergy of the dioceses of Waterford and Lismore (Waterford, 1920), pp 54,116). Thomas Rys is not listed among canons of Cork in Cotton, Fasti, ii.

${ }^{48}$ See R. N. Swanson, 'Titles to orders in medieval English episcopal registers' in Henry Mayr-Harting and R. I. Moore (eds), Studies in medieval history presented to R. H. C. Davis (London, 1985), pp 233-45.

${ }^{49}$ Virginia Davis, 'Late medieval English clergy database' in History and Computing, ii (1990), pp 84-5.
} 
Irishmen in England rarely cite for their title a religious house situated in Ireland. Only a few occurrences of this have been found, most rather late in date. Mellifont abbey is listed as giving a title to Richard Mabysine in $1437,{ }^{50}$ while Nicholas Comyn of the diocese of Lismore, who took an M.A. at Oxford University and was ordained in Magdalen College, Oxford, in 1505, had a title from the Cistercian abbey of Tintern in County Wexford ${ }^{51}$

Some English houses, however, seem regularly to have offered titles to Irishmen seeking ordination. In practice, what this is likely to mean is that the house had inspected the proffered details of means of support and then certified that it was adequate, so enabling the ordinand to proceed to the ceremony. ${ }^{52}$ Among the houses most commonly cited by Irish candidates for ordination were two in London, the substantial Augustinian priory of Holy Trinity, and Clerkenwell nunnery. However, what is more striking is the wide range of houses cited by the Irish ordinands, almost seventy of them. Some of the houses cited suggest a degree of mobility on the part of the Irish candidate for ordination. John Gaynard, of the Irish diocese of Emly, who was ordained deacon in 1441 in Wells, cited the Sussex priory of Boxgrove as his title, ${ }^{53}$ while Patrick Olomchore, ordained priest in Winchester cathedral in 1451, had a title from St Gregory's priory in Canterbury. ${ }^{54}$ It is difficult to reconstruct the experiences of such individuals. How did they select a religious house which would vouch for their title once they had left their native land? Had they been living in England for some time and therefore had chosen an institution close to where they were based? Without additional information, it is impossible to reconstruct the scenario satisfactorily. Take for example the case of Richard Asshe, of the diocese of Dublin, who was ordained at Chudleigh parish church in the diocese of Exeter in 1446. His title was from the Augustinian abbey of Hartland, which is situated on the north-western tip of the Devonshire coast. Did he land at some south-western port, most probably Bristol? If so, why did he choose to go to Hartland abbey for certification as to his title? It is possible that he had some previous connexion with the area; it is known that he subsequently became a chaplain at Stratton in Cornwall, which is only about ten miles away from Hartland abbey. ${ }^{55}$

A title from a religious house allowed men to proceed to ordination, but it did not mean that they maintained links with that house; essentially it was an administrative procedure. Some of these Irishmen were clearly intent on

\footnotetext{
${ }^{50}$ Reg. Gilbert, f. 152v (Guildhall Library, London, MS 9531/6).

${ }^{51}$ Registrum Ricardi Mayew, episcopi Herefordensis, ed. A. T. Bannister (Oxford, 1919), pp 242-3; B.R.U.O., p. 476. He is likely to be the man of the same name who became bishop of Ferns in 1510 and was translated to Waterford in 1519. Other Irish houses giving titles were the Dublin houses of St Thomas the Martyr and Holy Trinity priory and Graiguenamanagh abbey in County Kilkenny.

${ }^{52}$ Swanson, 'Titles to orders', pp 233-45.

${ }^{53}$ Reg. John Stafford, ii, 396.

${ }^{54}$ Reg. Waynflete, f. Dr (Hampshire Record Office).

${ }^{55}$ The register of Edmund Lacy, bishop of Exeter, 1420-55, ed. G. R. Dunstan (5 vols, London, 1963-72), iv, 210, 211, 213; iii, 61, records that Richard Asshe paid $6 s .8 d$. in tax in 1449 .
} 
making a career in England and went on to do so. They can be traced, obtaining benefices and pursuing successful careers. Richard Castlemartyn of Meath diocese, ordained in 1457 with a title from the Canterbury nunnery of St Sepulchre, was in the mid-1460s successively instituted to first Bircholt and then Burmarsh rectories, both in the diocese of Canterbury. It is not known how Castlemartyn attracted the attention of the patrons of these two benefices; Bircholt's patron was Thomas Evenette, while the patron of Burmarsh was the Canterbury priory of St Augustine. ${ }^{56}$

More revealing evidence of links with sponsors can be seen in those instances where the ordinand gave more specific details as to his patronage or the source of his income. Here we can see the role being played by members of the Anglo-Irish community in supporting aspiring ordinands. Nicholas Hert of Kildare diocese was ordained in Ely cathedral in the early 1420 s with a title derived from Gerald fitz Maurice FitzGerald, fifth earl of Kildare. ${ }^{57}$ A rare survival in Archbishop's Fleming's Armagh register shows us this personal sponsorship at work in an Irish context. The register contains a letter of title for ordination dated May 1410 from Walter Plunket, lord of Beaulieu, County Louth, in favour of Peter Chambre, a deacon seeking promotion to the priesthood. Plunket granted Chambre 5 marks yearly rent out of his lands in Kerestown, County Louth, until Chambre obtained a satisfactory benefice. ${ }^{58}$ It is this sort of grant that accounts for the similar references in the English episcopal ordination lists in 1376 noting that Richard Crosby of Armagh diocese was being supported by 6 marks of rents in Smithstown from the lands and rents of Robert Naptone, ${ }^{59}$ and that John Stakboll was supported by lands and tenements in Kilmanagh, County Kilkenny, belonging to John Blackbourne. ${ }^{60}$ Joint sponsors, John Wike, lord of Wike, and John Gibbes, burgess of Oxford, who provided 6 marks of land in Wike, Oxfordshire, in 1369 and 1367, supported two men, John Ledred of Ossory and John White of Meath. This is likely to be connected with the pursuit of education. Wike is a hamlet north-west of Oxford, and John Gibbes can be identified with the man of the same name who is described as vintner in the 1380 Oxford poll tax.

Education was clearly one important motive for some Irish clergy coming to London, but we must beware of thinking it was the only one. Those who attended the relatively well-documented colleges of Oxford and Cambridge were very much an élite. The ordination lists help to identify some of those who came to spend a period there but who did not belong to a prestigious college and were perhaps attached to one of the more ephemeral and shadowy halls which provided lodgings for many students. Emden in his pioneering work on graduates of Oxford and Cambridge

${ }^{56}$ Registrum Thome Bourgchier, Cantuariensis archiepiscopi, 1454-1486, ed. F. R. H. Du Boulay (Oxford, 1957), pp 280, 294-5, 366.

${ }^{57}$ Reg. Fordham, f. 108r (Cambridge University Library, EDR G/1/3).

${ }^{58}$ Lawlor (ed.), 'Calendar of Archbishop Fleming's register', no. 124 (p. 132). 283.

${ }^{59}$ Reg. Sudbury (Canterbury), f. 140r (Lambeth Palace Library); Reg. Wykeham, i,

${ }^{60}$ Reg. Wykeham, i, 281, 285. 
made the assumption that those who gave as their title at ordination religious houses close to the universities, such as Osney abbey, St Frideswide's, Rewley abbey and Godstow nunnery near Oxford, were in fact students at the university, even when there was no other evidence to substantiate this. ${ }^{61}$ A number of Irish students fall into this category, including Adam Calfheard, Adam Bryt and Andrew Waryng. ${ }^{62}$

The ordination lists therefore provide us with a series of tantalising hints - hints of links between lords and patrons, hints of more information about the élite going to study in Oxford and Cambridge, hints of a substantial body of clergy in late medieval England who came from the AngloIrish community. Looking at this material, one is struck by two things: first, the London-dominated nature of their migration; and second, the peaks of migration in the $1360 \mathrm{~s}-1370 \mathrm{~s}$ and the $1430 \mathrm{~s}-1440 \mathrm{~s}$. The history of the Irish clergy in England remains to be written, and the ordination lists are only one source for it - they need to be used in conjunction with Oxford and Cambridge collegiate material, with papal records and with government records. The ordination lists, however, provide a valuable snapshot of a group of largely Anglo-Irish clergy in England, at a moment when they are starting out upon their ecclesiastical careers. ${ }^{63}$

VIRGINIA DAVIS Department of History, Queen Mary and Westfield College, University of London

${ }^{61}$ B.R.U.O., p. xxxviii.

${ }^{62}$ Ibid., pp 340, 1996; B.R.U.C., p. 103.

${ }^{63}$ This is a version of a paper first given at a conference on the Irish in medieval England held at Queen Mary and Westfield College, University of London, in 1995. I am grateful for all the helpful comments made by the participants at that conference. 